\title{
Investigation of Structural and Spectroscopic Properties of Nanostructured CdS Films
}

\author{
P.K. Mochahari \\ Department of Physics, D.K.D. College, Dergaon, Assam, India \\ Corresponding author: mochaharip@ rediffmail.com, Tel: 9435092953
}

Available online at: www.isroset.org

Received: 09/Nov/2017, Revised: 17/Nov/2017, Accepted: 14/Dec/2017, Published: 31/Dec/2017

\begin{abstract}
Nanostructured cadmium sulphide (CdS) films have been prepared on glass substrates by chemical bath deposition (CBD) method at room temperature. Analysis of the samples by x-ray diffraction (XRD) exhibits the films have cubic phase structure of CdS. Different structural parameters such as crystallite size (using Scherrer's relation) and dislocation density of the samples have been estimated. Optical absorption spectra of the sample falls in the visible region and various optical parameters such as optical band gap energy (using Tauc's formula), refractive index as well as dielectric constant have been calculated. Chemical composition of the samples has been investigated using fourier transform infra red (FTIR) spectroscopy.
\end{abstract}

Keywords- XRD, optical band gap, refractive index, FTIR

\section{INTRODUCTION}

During recent decade, nanomaterials have attracted great interest and attentions due to their unique characteristics that differ from that of the bulk materials. The novel properties of nanomaterials are size, structure and shape dependent. Semiconductor II-VI nanomaterials have received much importance due to their unique mechanical, optical and magnetic properties as well as applications in various fields. Cadmium sulphide belongs to II-VI group material and it is a special material having direct wide band gap energy $(2.42 \mathrm{eV}$ in bulk form) and high refractive index (2.5). It has wide range of applications in numerous areas including multilayer light emitting diode [1], field effect transistor, gas sensor [2], photovoltaic cell [3], optoelectronic devices [4] and many more. Different workers have adopted various techniques to prepare CdS nonmaterials such as sputtering [5], spray pyrolysis [6], electrochemical deposition [7], pulsed laser deposition [8], vacuum deposition [9], chemical deposition, etc. Chemical bath deposition [10] is a simple, widely used, cost effective method which allows large area deposition. In our present paper synthesis of nanostructured CdS films using CBD method and structural, optical as well as spectroscopic investigations are reported.

This paper has been organized into four distinct sectionsIntroduction, Materials and Methods, Results and discussion and conclusions. In introduction section brief literature review related to our present work is presented. Materials and Method section contain the materials used for the preparation of nanostructured $\mathrm{CdS}$ film and details of preparation as well as the characterization instruments used.
Results and discussion section provides XRD spectra, optical absorption spectra, FTIR spectra of nanostructured CdS films and analysis and discussion of the results obtained. In the conclusion section major conclusions drawn from the results are provided.

\section{MATERIAls AND MethodS}

\section{Materials}

Monohydrate cadmium chloride $\left(\mathrm{CdCl}_{2} \cdot \mathrm{H}_{2} \mathrm{O}\right)$ (pure), purchased from Merck specialties private limited, Mumbai, India, nonahydrate sodium sulphide $\left(\mathrm{Na}_{2} \mathrm{~S} .9 \mathrm{H}_{2} \mathrm{O}\right)$ (pure), purchased from Rankem, RFCL, New Delhi, India and polyvinyl alcohol (pure) purchased from sd fine CHEM limited, Mumbai, India were used for the preparation of nanostructured CdS films.

\section{Method}

Nanostructured CdS films have been synthesized by ion exchange reaction in the matrix of polyvinyl alcohol (PVA). The matrix solution was prepared by adding $\mathrm{CdCl}_{2}$ solution having 1.0 molarity to an aqueous solution ( $4 \mathrm{wt} \%$ ) of PVA in equal volume under a high stirring rate $200 \mathrm{rpm}$ for 3 hours at constant temperature $70^{\circ} \mathrm{C}$. The prepared solution was kept for 12 hours for complete dissolution. Next, $\mathrm{Na}_{2} \mathrm{~S}$ solution having 0.25 molarity was added to the above solution till the whole solution turns into yellow colour and stirred for 15 minute. The final CdS solution was casted on cleaned glass substrates and are allowed to dry in a closed chamber at room temperature to yield nanostructured $\mathrm{CdS}$ films. 


\section{Characterization}

Structural characterization of prepared nanostructured CdS film was done by XRD using Bruker (AXS D8 Advance) with $\mathrm{CuK} \alpha$ radiation $(\lambda=1.5406 \AA)$. CARY 300 Scan UVVisible spectrophotometer was used to record optical absorption spectra in the wavelength range $350 \mathrm{~nm}-800 \mathrm{~nm}$ at room temperature. Fourier transform infra red (FTIR) spectra of nanostructured CdS film was recorded in IR Affinity-1, SHIMADZU in the wavelength range of 4000 to $450 \mathrm{~cm}^{-1}$.

\section{RESUlts AND Discussion}

\section{X-Ray Diffraction (XRD) study}

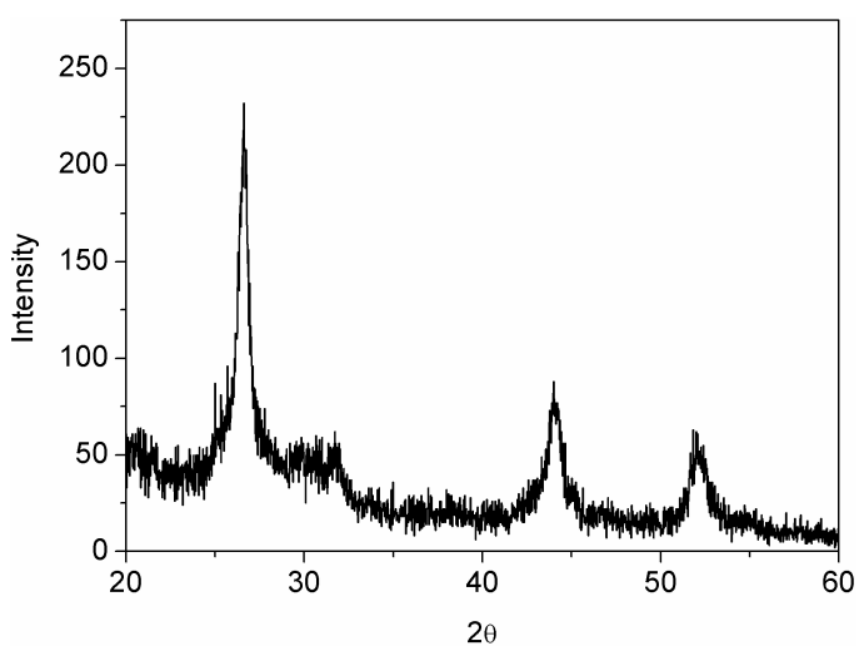

Fig 1: XRD pattern of nanostructured CdS film

XRD pattern of prepared nanostructured CdS film (1.0 molarity) is shown in Fig. 1. The XRD pattern exhibits three prominent and clear peaks centered at $2 \theta=26.73,44.23$, 52.41 which can be assigned to (111), (220) and (311) planes respectively of the CdS cubic crystalline phase (JCPDS800019). The peak position of (111) plane is found to shift towards higher diffraction angles by 0.183 compared to its corresponding value for bulk CdS $(2 \theta=26.547$; JCPDS 800019) indicating formation of compressive stress. The formation of compressive stress may be attributed to residual stress generated in the film during deposition or due to the lattice mismatch between the film and the substrate [11]. The formation of intense and broad diffraction peak profile indicates generation of good nanocrystal. The interplanar spacing $(d)$ is estimated from Bragg's equation $(\lambda=2 d \sin \theta)$.

The calculated value of lattice constant $(a)$ is found from the relation $a=d\left(h^{2}+k^{2}+l^{2}\right)^{1 / 2}$. The values of both interplanar spacing $(d)$ and lattice constants are cited in Table 1 . The crystallite size $(D)$ of the prepared sample is estimated using Scherrer's formula [12].

$$
D=\frac{K \lambda}{\beta \cos \theta}
$$

Where $K$ is a constant equal to $0.94, \lambda$ is the wavelength of the radiation which is $1.54056 \AA$ for $\mathrm{CuK}_{\alpha}$ radiation, $\beta$ (in radian) is the full width at half maximum (FWHM) of the peaks and $\theta$ is the Bragg's diffraction angle. The calculated value of crystallite size is cited in Table 1.

Dislocation density of nanostructured $\mathrm{CdS}$ film has been estimated using the relation [13]

$$
\text { Dislocation density }(\delta)=1 / D^{2}
$$

Where $D$ is the crystallite size. The estimated value of dislocation density of the sample is cited in Table 1.

Table 1 Structural parameters of nanostructured CdS film

\begin{tabular}{|l|l|c|c|c|c|c|}
\hline Sample & $\begin{array}{l}2 \theta \\
(\text { degree })\end{array}$ & $\begin{array}{c}d \\
\text { value } \\
(\AA)\end{array}$ & $(h k l)$ & $\begin{array}{c}a \\
(\AA)\end{array}$ & $\begin{array}{c}\text { Crystallite } \\
\text { size } D \\
(\mathrm{~nm})\end{array}$ & $\begin{array}{c}\text { Dislocation } \\
\text { density } \\
(\delta \\
\left.\times 10^{16} / \mathrm{m}^{2}\right)\end{array}$ \\
\hline \multirow{2}{*}{$\begin{array}{l}\mathrm{CdS} \\
(1.0 \mathrm{M})\end{array}$} & 26.73 & 3.332 & $(111)$ & 5.772 & \multirow{2}{*}{9.5813} & \multirow{2}{*}{1.0595} \\
\cline { 2 - 5 } & 44.23 & 2.046 & $(220)$ & 5.787 & & \\
\cline { 2 - 5 } & 52.41 & 1.744 & $(311)$ & 5.785 & & \\
\hline
\end{tabular}

\section{Optical absorption study}

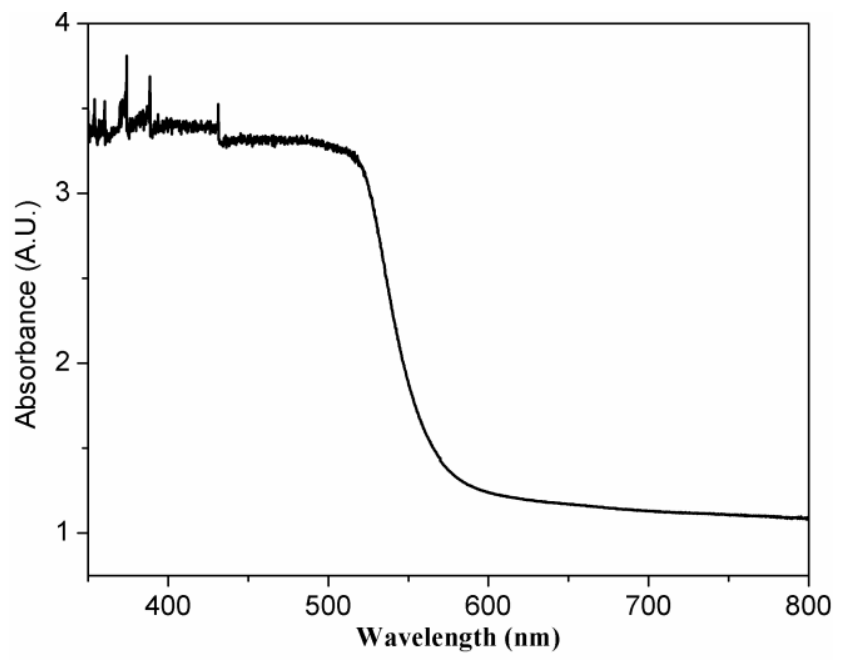

Fig 2: Absorption spectra of nanostructured CdS film

The knowledge of optical absorbance and band gap energy is important for material to be used in the solar cell fabrication. Fig. 2 shows optical absorbance curve in the range 350- 800 $\mathrm{nm}$ for 1.0 molarity nanostructured $\mathrm{CdS}$ film deposited at room temperature. Optical absorption spectra of the sample shows sharp absorption edge in the visible region which 
indicates good crystallianity as well as low defect density near band edge [14].

The optical band gap energy $\left(E_{g}\right)$ is estimated using Tauc's formula [15]

$$
(\alpha h v)^{1 / n}=A\left(h v-E_{g}\right)
$$

Where $\alpha$ is the absorption co-efficient, $h v$ is incident photon energy, $A$ is a constant. Since $\mathrm{CdS}$ is a direct band gap material, so, $n=1 / 2$ for allowed transition. Band gap energy has been found by extrapolating the linear region of the plots $(\alpha h v)^{2}$ versus $h v$ on the energy axis as shown in Fig. 3. The band gap energy is found to be $2.56 \mathrm{eV}$ (cited in Table2) which is blue shifted compared to the value of bulk CdS and it is attributed to size (quantum confinement) effect [16].

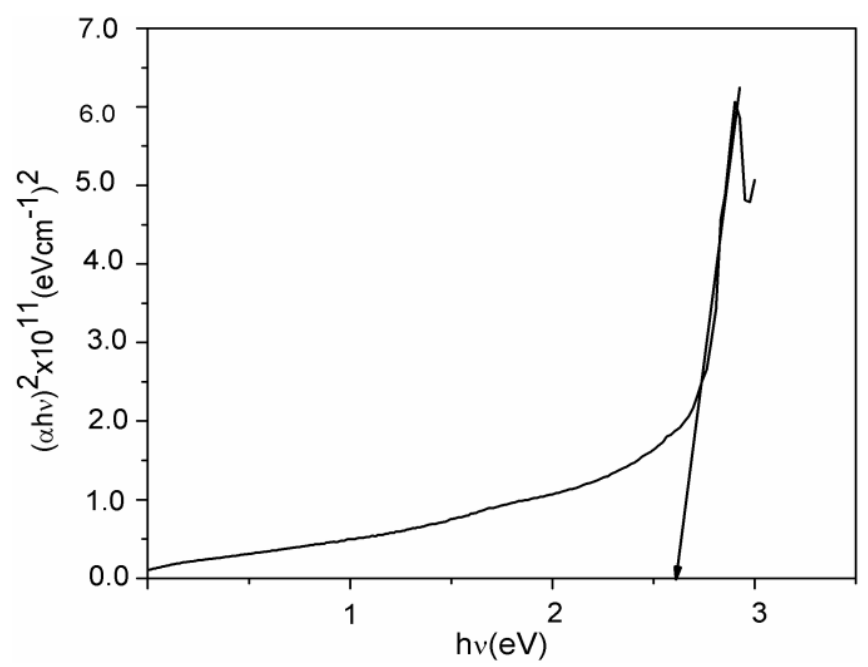

Fig 3: $(\alpha h v)^{2}$ vs $h v$ plot of nanostructured CdS film for band gap determination

Refractive index for the prepared sample is determined from the relation given by Herve and Vandamme [17]

$$
n=\sqrt{1+\left(\frac{A}{E_{g}+B}\right)^{2}}
$$

Where $A=13.6 \mathrm{eV}$ and $B=3.4 \mathrm{eV}$ are constants. This relation is accurate for the materials having high band gap. The estimated value of refractive index for the sample is cited in Table 2 .

Optical dielectric constant $\left(\varepsilon_{\alpha}\right)$ is calculated from the relation [18]

$$
\varepsilon_{\alpha}=n^{2}
$$

Where $n$ is the refractive index. The estimated value of dielectric constant for the sample is cited in Table 2.
Table 2 Optical parameters of nanostructured CdS film

\begin{tabular}{|l|l|l|l|}
\hline Sample & $\begin{array}{l}\text { Band } \\
\text { energy, } E_{g}(\mathrm{eV})\end{array}$ & $\begin{array}{l}\text { Refractive } \\
\text { index }\end{array}$ & $\begin{array}{l}\text { Dielectric } \\
\text { constant }\left(\varepsilon_{\alpha}\right)\end{array}$ \\
\hline CdS $((1.0 \mathrm{M})$ & 2.56 & 2.49 & 6.20 \\
\hline
\end{tabular}

Fourier Transform Infrared (FTIR) study

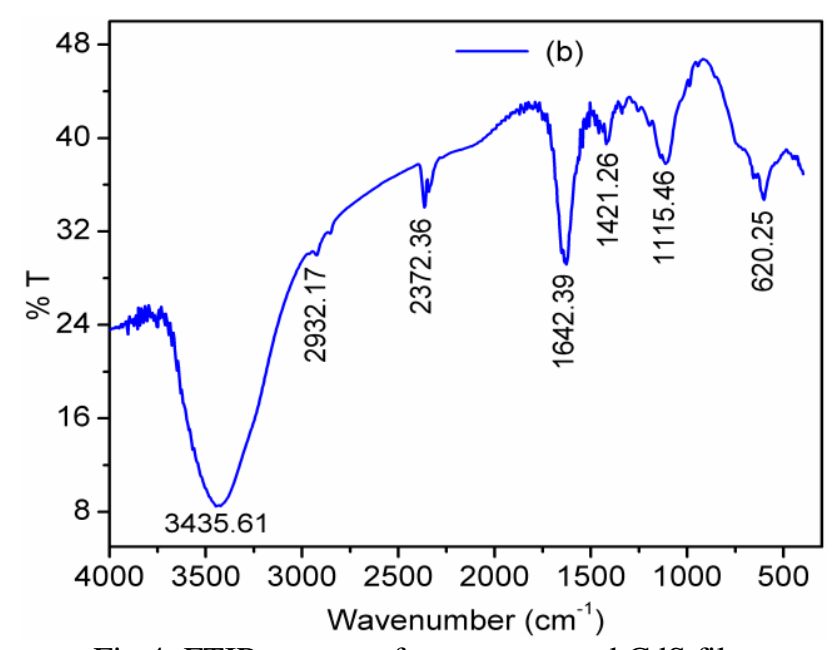

Fig 4: FTIR spectra of nanostructured CdS film

FTIR spectroscopy is an important technique to determine the functional group. It is a useful method to find bond vibration frequency in a molecule. FTIR spectra of nanostrutured CdS sample prepared in PVA matrix at room temperature is shown in Fig. 4. The absorption band at $3435.61 \mathrm{~cm}^{-1}$ is attributed to the $\mathrm{O}-\mathrm{H}$ stretching vibration of water molecule [19]. The band at $2932.17 \mathrm{~cm}^{-1}$ is due to $\mathrm{C}-\mathrm{H}$ stretching. The absorption band which appears at 1642.39 $\mathrm{cm}^{-1}$ is assigned to $\mathrm{C}=\mathrm{O}$ stretching. The absorption band at $1421.26 \mathrm{~cm}^{-1}$ is due to $\mathrm{C}-\mathrm{H}$ stretching. Trace amount of $\mathrm{SO}_{4}^{-}$ is observed with the appearance of absorption band at $1115.46 \mathrm{~cm}^{-1}$ [20]. The medium band at $620.25 \mathrm{~cm}^{-1}$ has been assigned to Cd-S stretching [21].

\section{CONCLUSION AND Future ScOPE}

Good quality nanostructured $\mathrm{CdS}$ films have been successfully synthesized on glass substrates by chemical bath deposition method. Structural study using XRD method shows the formation of cubic phase structure and crystallite size of the sample is found to be $9.5813 \mathrm{~nm}$ whereas dislocation density is $1.0595 \times 10^{16} / \mathrm{m}^{2}$. The band gap energy of the sample estimated to be $2.56 \mathrm{eV}$ is blue shifted compared to the value of bulk $\mathrm{CdS}$ due to quantum confinement effect. Refractive index and dielectric constant are found to be 2.49 and 6.20 respectively. Investigation of FTIR spectra shows the stretching modes of the sample. We plan to study electrical and magnetic properties of the nanostuctured CdS films as our future work. 


\section{REFERENCES}

[1] J. Zhao, J. A. Bardecker, A. M. Munro, et al., "Efficient CdSe/CdS Quantum Dot Light-Emitting Diodes Using a Thermally Polymerized Hole Transport Layer", Nano Lett., Vol. 6, pp 463-467, 2006.

[2] L. Yadava, R. Verma, R. Dwivedi, "Sensing properties of CdSdoped tin oxide thick film gas sensor", Sensors and Actuators B: Chemical, Vol. 144, pp. 37-42, 2010.

[3] G. Larramona, C. Choné, A. Jacob, et al., "Nanostructured Photovoltaic Cell of the Type Titanium Dioxide, Cadmium Sulfide Thin Coating, and Copper Thiocyanate Showing High Quantum Efficiency", Chem. Mater., Vol. 18, pp. 1688-1696, 2006.

[4] K. J. Wu, K. C. Chu, C. Y. Chao, Y. F. Chen, "CdS Nanorods Imbedded in Liquid Crystal Cells for Smart Optoelectronic Devices", Nano Letters, Vol. 7, pp. 1908-1913, 2007.

[5] N. R. Paudel, K. A. Wieland, A. D. Compaan, "Ultrathin CdS/CdTe solar cells by sputtering", Solar Energy Materials and Solar Cells, Vol. 105, pp. 109-112, 2012.

[6] A. H. Rubel, J. Podder, "Structural and Electrical Transport Properties of CdS and Al-doped CdS Thin Films Deposited by Spray Pyrolysis", J. Sci. Res., Vol 4, pp.11-19, 2012.

[7] S. P. Mondal, A. Dhar, S. K. Ray, "Optical properties of $C d S$ nanowires prepared by dc electrochemical deposition in porous alumina template", Materials Science in Semiconductor Processing, Vol. 10, pp. 185-193, 2007.

[8] B. Ullrich, H. Sakai, Y. Segawa, "Optoelectronic properties of thin film CdS formed by ultraviolet and infrared pulsed-laser deposition", Thin Solid Films, Vol. 385, pp. 220-224, 2001.

[9] A. Ashour, N. El-Kadry, S. A. Mahmoud, "On the electrical and optical properties of CdS films thermally deposited by a modified source", Thin Solid Films, Vol. 269, pp. 117-120, 1995.

[10] G. Sasikala, P. Thilakan, C. Subramanian, "Modification in the chemical bath deposition apparatus, growth and characterization of $\mathrm{CdS}$ semiconducting thin films for photovoltaic applications", Solar Energy Materials and Solar Cells, Vol. 62, pp. 275-293, 2000.

[11] D. Bhattacharyya, M. J. Carter, "Effect of substrate on the structural and optical properties of chemical-bath-deposited CdS films", Thin Solid Films, Vol. 288, pp. 176-181, 1996.

[12] S. Sen, S. K. Halder, S. P. Sengupta, "An X-ray line broadening analysis in the vacuum-evaporated silver films", J. Phys. Soc. Japan, Vol. 38, pp. 1641-1647, 1975.

[13] S. Senthilarasu, R. Sathyamoorthy, S. Lalitha, "Synthesis and characterization of $\beta$-FeSi2 grown by thermal annealing of $\mathrm{Fe} / \mathrm{Si}$ bilayers for photovoltaic applications", Solar Energy Materials \& Solar Cells, Vol. 82, pp. 299-305, 2004.

[14] J. Cheng, D. B. Fan, H. Wang, et al., "Chemical bath deposition of crystalline ZnS thin films", Semicond. Sci. Technol. Vol. 18, pp. 676-679, 2000.

[15] J. Tauc (ed.), "Amorphous and liquid semiconductors", Plenum publication, New York, pp. 159, 1974.

[16] R. Banerjee, R. Jaykrishnan, R. Banerjee, P. Ayyub, "Effect of the size-induced structural transformation on the band gap in CdS nanoparticles", Journal of Physics: Condensed Matter, Vol. 12, pp.10647, 2000.

[17] P. Herve, L. K. J. Vandamme, "General relation between refractive index and energy gap in semiconductors", Infrared Phys. Technol. Vol. 35, pp. 609-615, 1994.

[18] G. A. Samara, "Temperature and pressure dependences of the dielectric constants of semiconductors", Phys. Rev. B, Vol. 27, pp. 3494-3505, 1983.
[19] R. Devi, P. Purkayastha, P. K. Kalita, B. K. Sarma, "Synthesis of nanocrystalline CdS thin films in PVA matrix", Bull. Mater. Sci. Vol. 30, pp. 123-128, 2007.

[20] D. H. Williams, I. Fleming, "Spectroscopic methods in organic chemistry", (Tata McGraw-Hill: New Delhi) 5th ed., pp. 57, 2004.

[21] A. Periasamy, S. Gunasekaran, et al., Proceedings of national conference on spectrophysics (ed.), pp. 95, 1997.

\section{AUTHOR PROFILE}

Dr. Prince Kumar Mochahari pursued BSc. from St. Anthony's College, Shillong. He did MSc. in Physics from NEHU, Shillong. He obtained $\mathrm{PhD}$ degree from Gauhati University in the year 2016. His area of study during $\mathrm{PhD}$ research work is Thin Film Nano and ion implantation in the sample materials. $\mathrm{He}$ is currently working as Asstt. Professor in the department of Physics, D.K.D.College, Dergaon, Assam, India. He has published good number of research papers in reputed international journals including SCI. Moreover he has presented large number of research papers in international and national conferences/seminars. 